\title{
Attaining Customer Satisfaction! The Role of Customer Value and Relation Base Marketing A Study of Policy Holders of Peshawar Pakistan
}

\author{
SHAHZAD KHAN \\ Lecturer City University of Science and I-T Peshawar Pakistan \\ Email: Shahzadkhan.lecturer@gmail.com
}

Phone: +92-3339405596

\begin{abstract}
Consumer satisfaction is always a question mark in minds of sellers as it is very difficult to find that what exactly consumer want from the seller. For the very same reason this research is conducted that how customer satisfaction can be gained with the help of customer value and relation base marketing. Customer satisfaction is one of the most important issues in marketing field from beginning and its play a crucial role in firm profit maximization. Study collect data from 150 policy holders of different insurance companies of Peshawar Pakistan on systematic random sampling method. A structured questionnaire used to collect data from the respondents. Study shows that value added services and conflict handling are the major reason for the customer satisfaction. Managers can use this study and can implement these findings in their business for their customer satisfaction and more money earnings.
\end{abstract}

Key Words: Customer, Value, Satisfaction and Relationship Marketing.

\section{Introduction}

At the end of selling era, marketing era start emphasizing on customer satisfaction and providing more superior value as compare to competitors to the target market. Later the concept of societal marketing involves society wellbeing and relations base offering. All over the world the issue of customer satisfaction is under consideration and for this satisfaction relation play a very vital role. Does for satisfaction only four ps are responsible only? One more important dimension is the relationship with consumers. Now it depends upon nature of business and offering that does relation base marketing needed in that business and if needed at what level that relation base marketing is required. The high involvement and service are the prominent example for the relation base marketing. Like insurance, telecoms and education institution are the major's examples in which relation base marketing is required. This study is also emphasizing the role of relation base marketing contribution towards customer value which leads customer satisfaction. Relation base marketing is social process between seller and buyer.

Relations play a very vital role in making customer value. In the insurance industry relation base marketing play a major role. Insurance is a long lasting service and the antecedents of relations contribute towards ultimate value of consumers. Customer value is the benefit and cost analysis of a consumer for a product or service. Antecedents of relations contribute in some way towards the customer value. Greater the customer value more customer satisfaction. Relation base marketing is even more then consumer expectations. This is the relations which company provide and its take consumers towards more satisfaction what they expect. Even relation base marketing 
International Journal of Managing Value and Supply Chains (IJMVSC) Vol. 4, No. 1, March 2013

considered now as a asset and an competitive advantage. Greater the relations between suppliers, distributors and consumers greater the return for the company. But it will depend upon the relations that either the relation are positive or negative in nature. The study of [1] that there is a number of enrichment in the field of relations base marketing. Most of the issue discussed on the development of relation for the business purposes. Relation base marketing is a process which based on continuity and it does not bring results at once. For maintaining goods business relation, it take real time information about the parties which are involved and they must be understand for the communication or any other activity.

\section{Literature Review}

\section{Customer Satisfaction}

Previous researches have given significant importance to customer satisfaction. Satisfaction can be defined as a features or characteristics that can full the either a need or want of a consumer in better way than competitors. Although this satisfaction explained by different researchers in different ways. If a company provides a product according to the requirements of their consumers it will lead the satisfaction of those consumers. The higher or lower satisfaction of a consumer will depends upon the quality of brand characteristics that offered by a company [2]. This is the consumer satisfaction which contributes for the future money making for a company [3]. For the retention of consumer, it is important to satisfied consumers [4]. The unsatisfied consumers of a company do not take time to switch that brand [5]. Low quality services can also lead dissatisfaction. A low quality service is such type of service which does not fulfill the requirements [6]. However its all depends upon that which segments a company is targeting and what are their expectations for that product [7]. In the study of [5] he explain that customer satisfaction is the key factor which is used to measure the company internal and external performances and assigning funds to each and every activity. Service is a key factor for consumer satisfaction although this is not the only factor which is responsible [5]. The study of [6] discuss that customer satisfaction has positive relationship on loyalty. The study of [7] that there are strong relations between satisfaction and loyalty. The study of [8] describe that for customer loyalty it is important to satisfy them. The study of [9] describe that there is a strong association between customer satisfaction and loyalty. The study of [10] describe that customer satisfaction lead customer loyalty. The study of [11] describe in their study that customer satisfaction is an important indicator for the customer loyalty. The study of [12] shows that relation base marketing creates customer value and value lead customer satisfaction [27].

\section{Customer Value}

In the study of [13] explain that customer value is the positive difference between the benefit customer gain and the cost a customer pay in order to gain the product. He explains that there are four types of benefits and four types of cost that a customer faces [26].

\section{Customer Benefits}

The first benefit that a customer gain is product that product must be in functioned condition and should solve the problem of the customers. The second benefit he explains is the image of the brand that company is providing. Stronger the image greater the advantage for consumers. $\mathrm{He}$ also explains that customers are some time provided with personnel benefit. The fourth benefit is the value added services which is provided to customer. In the study of [14] describe that relation base marketing is a benefit to consumer and increasing benefit obviously increased value. The value added services can further be enriched with help of relation base marketing [28]. 


\section{Relationship Marketing}

According to study of [12] that relationship is the state of being connected or related. It is the association either by blood or through social environment. Relations base marketing is actually the dealings, connections or feelings that exist between seller and buyer. This connection can be base on rational or either emotions. Relationship marketing is a strategy in which a company seeks to build long term relationship with its customer by providing and increasing their customer value to satisfy them towards their offerings. In order to maximize the customer value it is important to ensure good relationship with consumers. The goal of relationship marketing is ensuring value to consumer for the long term and producing enduring customer satisfaction. This is the reason due to which the modern marketing switches towards societal marketing concepts instead of emphasizing only on marketing only. And this is the reason due to which the concept of customer relation marketing evolved because relation base marketing has positive effects on firm marketing performances.

\section{Dimensions of Relationship Marketing}

There are eight key dimensions of relationship marketing: bonding, tangibility, empathy, reciprocity, trust, commitment, communication and conflict handling. These eight factors are very important for good relation base marketing. Because these factors contribute for consumer value which lead further to customer satisfaction that latterly can be converted into loyalty. These factors are explaining bellow one by one in details that how they contribute for relation base marketing.

\section{Bonding}

Both Seller and buyer must be link together for the long term in order to have a long term association with one another. Greater the positive association between two parties, more will be the pledge between them [15].

\section{Bonding Development}

\subsection{Making Promise}

Each and every marketing firm makes certain promises to their consumers regarding the brands company offering. These promises are not only restricted to consumers but also firms make promises to suppliers and distributors as well. These promises make expectation in other parties mind. These promises increase the expectations level of those parties. This is the reason that exaggeration is avoided by many good marketers in certain areas of offering. The promises of the company must be realistic and also consistent in nature. Because unrealistic promises will lead greater gap between customer expectation and reality. If the gap is negative it will lead dissatisfaction and may not buy the offerings of the company for the second time [15].

\subsection{Enabling Promises}

Marketing firms offer promises with external marketing activities like advertising, personnel selling and sale promotion etc. After offering the promises to consumers these can be enable with the help of internal marketing like good and skillful human resource. The skill full employee can understand and can more enhanced enable the promises made [15]. 
International Journal of Managing Value and Supply Chains (IJMVSC) Vol. 4, No. 1, March 2013

\subsection{Keeping Promises}

The external marketing efforts bring consumer in interaction with the firm and consumers take their final decision when firm keeps its promises. The relation between seller and buyer is based on the point at which the firm keeps its promises [15].

Transparently making, enabling, and keeping promises are the most important and prominent parts of relation base marketing. But relation base marketing is not only dependent upon these three factors.

\section{Emotions and Tangibility}

The study of [16] describe emotions play very important role in the relation base marketing and even some time emotions used for keeping promises [17]. Each and every relation needs physical aspects to build those relations stronger. The physical facilities, equipment and appearance of personnel can play vital role in the making of relation base marketing [18] These factors can be categorized situation to situation and business to business.

\section{Empathy}

According to study of [17] that it is important to understand the situation from the perspective of others. Empathy is the capability of a person to understand the circumstances from the aspect of involved party.

\section{Reciprocity}

Relation is a two way process. When it come to relationship marketing it is the process between seller and buyer. Both seller and buyer can be engaged in long term relation if both parties exchange certain things with each other. Company provide product in terms of good or either service or consumer pay in return in shape of money usually [17].

\section{Trust}

Trust is the faith which exists between two or more then two parties. In reality is the bond that keeps in touch two parties for the longer period of time. Trust is the belief or confidence of one party in another party. When two parties have more trust on each other it leads more assistance for both parties to keep that relation longer and make the decision faster [17].

\section{Commitment}

For the relation of the parties it is important to understand that how they are committed to keep that relation for the longer period of time. Greater commitment will lead a stronger relation between two parties. In case of relation base marketing it is important to understand the devotion of seller that how they are committed towards their consumers and for how long this commitment will be [19].

\section{Communication}

Communication is a two way process between sender and receiver. Communication can be verbal or nonverbal. For business relation it important to have and effective communication between seller and buyer. In order to establish good relations with consumers, companies invest huge amount of money on promotion in shape of advertising, personnel selling, sale promotion and public relation [20] 


\section{Conflict Handling}

It is important to resolve the conflict for good business relationship. Consumer switch to competitor brand because a certain conflict arise which does not solved effectively. For solving consumer conflict it is important to have a relation between seller and buyers. Stronger the relation easily the conflict can be resolved [17].

\section{Customer Cost}

In the study of [13] describe that there are four types of cost. The most prominent cost is price of the product or monetary cost. The study of [21] describe that price of the product is the most crucial cost that a customer pays for the product. In study of [22] discuss that company should reduce the price in order to create maximum value to consumers. The second type of cost is time that a customer consumes in buying of a product. Energy cost is also another cost at consumer side. To gain a product consumer waste its energy and also it psyche [23]. This is the reason that consumers are now a days fully provided in all aspect for one particular reason to reduce the customer over all cost [25]. Providing product in market, and ensuring that product is available at every retail store, all this because of one reason to reduce the customer time and energy cost. In certain product like technology involved items the concept of user friendly increasing for the reason to reduce the psyche cost of the product in order to increase value of the consumers [24].

\section{Hypothesis of the study}

On the basis of theoretical framework of the study following nine hypotheses has been developed. Table 1 below show hypothesis of the study.

\begin{tabular}{|l|l|}
\hline Objectives & Table 1 Hypothesis of the Study. \\
\hline $\begin{array}{l}\text { Relationship } \\
\text { between }\end{array}$ & H:1 Product benefit positive contribution towards customer value. \\
antecedents of & H:2 Brand image has significant impact on customer value. \\
relationship & H:3 Personnel benefit increase customer value. \\
marketing and & H:4a There is a positive relationship between customer value and bonding. \\
customer & H:4b Tangibility has a positive impact on customer value. \\
value. & H:4c There is a positive relationship between empathy and customer value. \\
& H:4d Reciprocity has an impact on customer value. \\
& H:4e Trust has a significant impact on customer value.. \\
& H:4f There is a positive relationship between Commitment and customer value. \\
& H:4g Communication has positive impact on customer value. \\
& H:4h Conflict handling has a significant impact on customer value. \\
& H:5 Reducing monetary/price cost increase customer value. \\
& H:6 Time cost reduction will increase customer loyalty. \\
& H:7 Energy cost reduction will lead positive customer value. \\
& H:8 Reducing Psychic cost of consumer will increase customer value. \\
& H:9 Customer value has direct positive influence on customer satisfaction. \\
& \\
\end{tabular}

\section{Theoretical Framework of the Study}

Research consists of the following research framework. Research has dependent variable in shape of customer satisfaction. While there are sixteen independent variables of this study. The sixteen independent variables are calcified into two groups. Ie customer value which is further subdivided into cost benefit and cost. The four benefits are product, image, personnel and service value. 


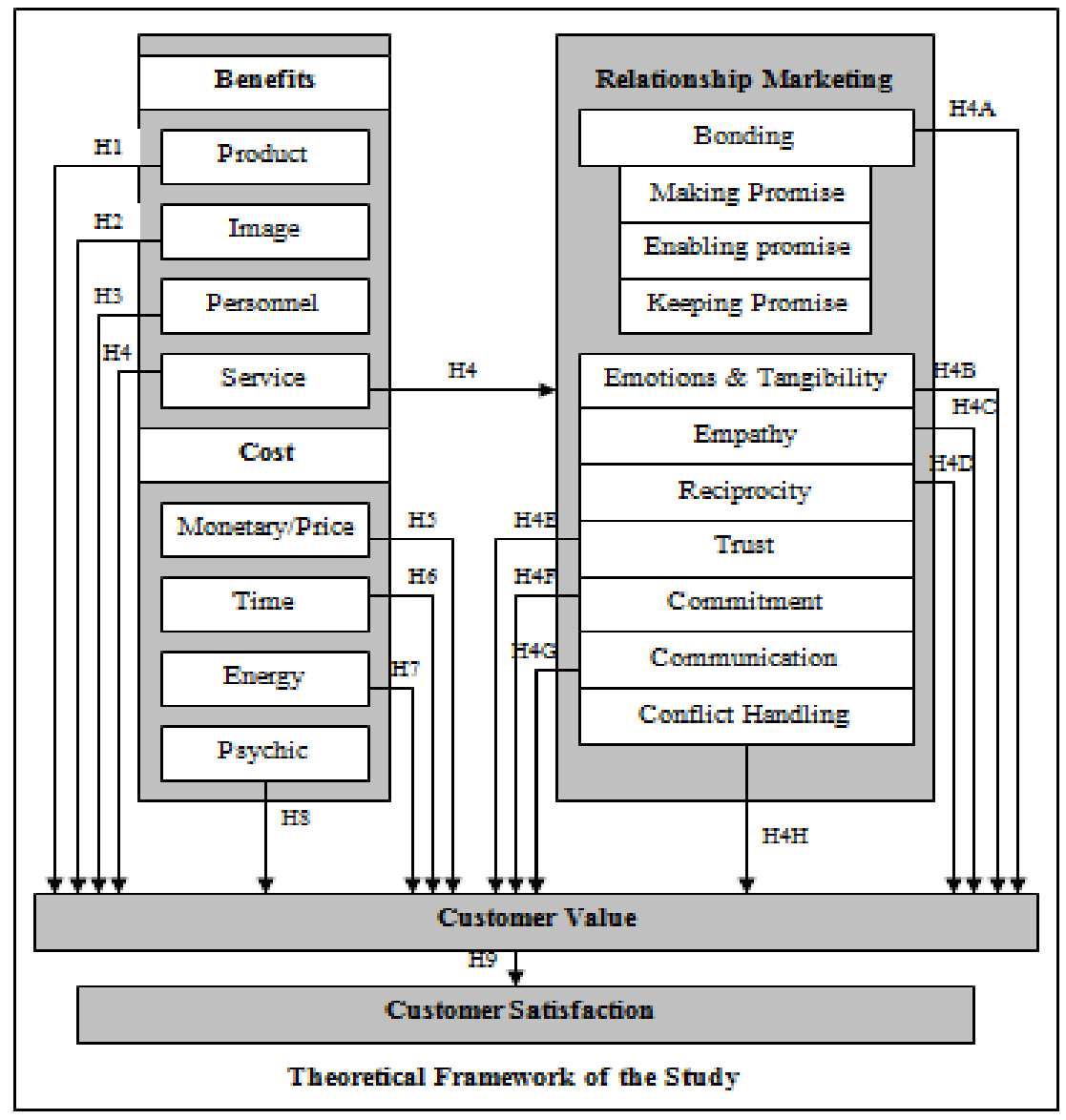

The service value is further subdivided into eight factors I,e boding, tangibility, empathy, Reciprocity, Trust, commitment, communication and conflict handling. The second part of the value is cost factor which includes four types of cost i,e monetary cost or price, time cost, energy cost and psychic cost.

The study represent that customer value is a mediator between the sixteen independent factors i,e eight antecedents of relationship marketing and eight factors of customer value.

While customer satisfaction is the dependent variable in the study. In other words customer satisfaction is dependent upon customer value and within customer value benefit side in term of services is based on antecedents of relationship marketing.

\section{Research Design}

\section{Data collection}

For research both primary and secondary data were collected. The methods will used for collecting primary and secondary data are as follows:

\section{Primary Data}

The method used to collect Primary data include questionnaires, from policyholders of insurance companies of Peshawar Pakistan. The items of questionnaire made and given in table 3. 


\section{Secondary Data}

Methods used to collect secondary data, include, research papers, circular, newsletters, journals and internet.

\section{Sample size and statistical tool}

The data collected through questionnaire from policyholders of insurance companies of Peshawar Pakistan in such a way that it covers the issues related to the topic.

The study use probability sampling for primary data collection. A systematic random sampling used for the sample selection. A sample 150 was contacted fro final analysis. For the analysis purpose of the study Correlation and multiple linear regression used to find the significance between customer value and antecedents of relation base marketing which are the independent factors of the study.

\section{Socio-Demographic Profile}

Table 2 below shows the demographical analysis of 100 respondents. Descriptive table below shows that $77 \%$ of the respondents are male and $23 \%$ respondents are female. Table 2 also explained that $7 \%$ respondents were in the age group of 20-25, while in age ranged from 26-21, $26 \%$ of respondents. While in age of 31-40 only $43 \%$ respondents and respondents having age more than 41 years are only $24 \%$.

Table 2: Demographical Result

\begin{tabular}{|c|c|c|c|}
\hline Measures & Items & Frequency & Percentage \\
\hline Gender & Male & 77 & $77 \%$ \\
& Female & 23 & $23 \%$ \\
\hline Age & $20-25$ & 7 & $7 \%$ \\
& $26-30$ & 26 & $26 \%$ \\
& $31-40$ & 43 & $43 \%$ \\
& $\geq 41$ & 24 & $24 \%$ \\
\hline Marital Status & Married & 81 & $81 \%$ \\
& Un -Married & 19 & $19 \%$ \\
\hline Income Per Month & Less than 20000 & 14 & $14 \%$ \\
& Above 20000 \& less then 30000 & 39 & $39 \%$ \\
& Above 30000 \& less then 40000 & 28 & $28 \%$ \\
& More than 40000 & 19 & $19 \%$ \\
\hline
\end{tabular}

The response of the study shows that $14 \%$ respondents have less then 20000 income per month. $39 \%$ respondents have income of more than 20000 and less then 30000 . Only $28 \%$ respondents are having income of more than 30000 and less then 40000 . While respondents have income more than 40000 are only $19 \%$.

There are five insurance companies which are operating in Peshawar KPK Pakistan. These companies are State Life Insurance, EFU insurance, American insurance company, New Jubilee Insurance and Takaful Insurance Company. From each company a sample of 20 respondents were contacted on convenient basis. 


\section{Summary of Measurement Scale}

The SPSS software which is use for the calculation of different variables such as mean, standard deviation ,factor loading, item reliability and composite reliability. The measurement model was used for construct reliability and validity. Construct reliability have two levels item reliability and composite reliability. Item reliability can be obtained by squaring the factor loading. Item reliability is greater than .50 is considered and less than .50 does not considered.

As shown in Table 3 all item reliabilities surpassed the required minimum, except one for perceive usefulness which was .38 below the required minimum. Composite reliability is greater than .70 than factor is reliable and if it is less than .70 than it is less reliable. With the exception of accessibility, the composite reliability for all the constructs was above .70

Table 3 Summary of Scale

\begin{tabular}{|c|c|c|c|c|c|}
\hline CONSTRUCT & MEAN & $\begin{array}{l}\text { STANDARD } \\
\text { DEVIATION } \\
\end{array}$ & $\begin{array}{c}\text { FACTOR } \\
\text { LOADING } \\
\end{array}$ & $\begin{array}{c}\text { ITEM } \\
\text { RELIABILITY }\end{array}$ & $\begin{array}{c}\text { COMPOSITE } \\
\text { RELIABILITY } \\
\end{array}$ \\
\hline \multicolumn{6}{|l|}{ Product Benefit } \\
\hline Product Benefit1 & 1.78 & 0.914 & 0.784 & 0.628849 & \\
\hline Product Benefit2 & 2.11 & 1.03 & 0.955 & 0.912025 & 0.919 \\
\hline Product Benefit3 & 2.23 & 1.193 & 0.98 & 0.9604 & \\
\hline \multicolumn{6}{|l|}{ Image } \\
\hline Image 1 & 2.41 & 1.376 & 0.92 & 0.8464 & \\
\hline Image 2 & 2.69 & 1.448 & 0.936 & 0.866096 & \\
\hline Image 3 & 2.34 & 0.928 & 0.815 & 0.658025 & 0.805 \\
\hline Image4 & 2.46 & 1.129 & 0.826 & 0.688896 & \\
\hline Image 5 & 2.80 & 1.114 & 0.642 & 0.499884 & \\
\hline \multicolumn{6}{|l|}{ Personnel } \\
\hline Personnel1 & 2.04 & 0.983 & 0.769 & 0.589121 & \\
\hline Personnel2 & 2.39 & 1.146 & 0.732 & 0.537076 & 0.943 \\
\hline Personnel3 & 2.47 & 1.132 & 0.937 & 0.878624 & \\
\hline Personnel4 & 2.59 & 1.076 & 0.934 & 0.880489 & \\
\hline \multicolumn{6}{|l|}{ Service } \\
\hline Service1 & 2.36 & 0.63 & 0.844 & 0.695456 & \\
\hline Service2 & 2.72 & 0.984 & 0.968 & 0.966484 & 0.899 \\
\hline Service3 & 2.57 & 1.215 & 0.912 & 0.823604 & \\
\hline \multicolumn{6}{|l|}{ 1. Bonding A } \\
\hline Bonding 1 & 2.34 & 0.853 & 0.913 & 0.842724 & \\
\hline Bonding 2 & 2.45 & 1.087 & 0.919 & 0.881184 & 0.972 \\
\hline Bonding 3 & 2.51 & 1.002 & 0.790 & 0.661601 & \\
\hline \multicolumn{6}{|c|}{ 2. Emotions \& Tangibility B } \\
\hline E\&T 1 & 2.03 & 0.886 & 0.916 & 0.857476 & \\
\hline E\&T 2 & 2.54 & 0.745 & 0.731 & 0.541225 & \\
\hline E\&T 3 & 2.63 & 0.795 & 0.730 & 0.530225 & 0.892 \\
\hline E\&T 4 & 2.32 & 0.644 & 0.843 & 0.696556 & \\
\hline E\&T 5 & 2.83 & 0.985 & 0.968 & 0.958484 & \\
\hline \multicolumn{6}{|l|}{ 3. Empathy C } \\
\hline Empathy1 & 2.27 & 0.865 & 0.968 & 0.852724 & \\
\hline Empathy2 & 2.43 & 1.081 & 0.918 & 0.871184 & 0.970 \\
\hline Empathy3 & 2.30 & 1.034 & 0.807 & 0.641601 & \\
\hline \multicolumn{6}{|l|}{ 4. Reciprocity D } \\
\hline Reciprocity1 & 2.36 & 0.617 & 0.874 & 0.696556 & \\
\hline Reciprocity2 & 2.83 & 0.985 & 0.988 & 0.996484 & 0.899 \\
\hline Reciprocity3 & 2.65 & 1.199 & 0.932 & 0.823604 & \\
\hline
\end{tabular}


International Journal of Managing Value and Supply Chains (IJMVSC) Vol. 4, No. 1, March 2013

\begin{tabular}{|c|c|c|c|c|c|}
\hline \multicolumn{6}{|l|}{ 5. Trust E } \\
\hline Trust1 & 2.24 & 0.855 & 0.918 & 0.842724 & \\
\hline Trust2 & 2.35 & 1.091 & 0.928 & 0.861184 & 0.959 \\
\hline Trust3 & 2.31 & 1.004 & 0.801 & 0.641601 & \\
\hline \multicolumn{6}{|l|}{ 6. Commitment $\mathrm{F}$} \\
\hline Commitment 1 & 2.39 & 0.64 & 0.834 & 0.695556 & \\
\hline Commitment2 & 2.73 & 0.995 & 0.978 & 0.956484 & 0.887 \\
\hline Commitment3 & 2.55 & 1.209 & 0.902 & 0.813604 & \\
\hline \multicolumn{6}{|l|}{ 7. Communication $\mathbf{G}$} \\
\hline Communication1 & 2.43 & 0.799 & 0.899 & 0.879633 & \\
\hline Communication2 & 2.62 & 1.203 & 0.917 & 0.896766 & 0.967 \\
\hline Communication 3 & 2.29 & 1.114 & 0.819 & 0.657218 & \\
\hline \multicolumn{6}{|l|}{ 8. Conflict Handling $\mathrm{H}$} \\
\hline Conflict Handling1 & 2.08 & 0.886 & 0.926 & 0.857476 & 0.811 \\
\hline Conflict Handling2 & 2.45 & 0.765 & 0.735 & 0.540225 & \\
\hline \multicolumn{6}{|l|}{ Monetary/Price } \\
\hline Monetary/Price1 & 2.47 & 0.810 & 0.878 & 0.697376 & \\
\hline Monetary/Price2 & 2.89 & 0.992 & 0.922 & 0.951473 & 0.898 \\
\hline Monetary/Price3 & 2.65 & 1.390 & 0.989 & 0.894178 & \\
\hline \multicolumn{6}{|l|}{ Time } \\
\hline Time1 & 2.56 & 0.892 & 0.985 & 0.830284 & \\
\hline Time2 & 2.89 & 1.784 & 0.901 & 0.845466 & 0.963 \\
\hline Time3 & 2.47 & 1.182 & 0.856 & 0.690272 & \\
\hline \multicolumn{6}{|l|}{ Energy } \\
\hline Energry1 & 2.78 & 0.886 & 0.926 & 0.857476 & 0.806 \\
\hline Energy 2 & 2.90 & 0.765 & 0.735 & 0.540225 & \\
\hline \multicolumn{6}{|l|}{ Psychic } \\
\hline Psychic1 & 2.90 & 0.679 & 0.874 & 0.698927 & \\
\hline Psychic2 & 2.67 & 0.983 & 0.990 & 0.979743 & 0.892 \\
\hline Psychic3 & 2.23 & 1.342 & 0.964 & 0.867438 & \\
\hline \multicolumn{6}{|l|}{ Customer Value } \\
\hline Customer Value1 & 2.14 & 0.899 & 0.900 & 0.864740 & \\
\hline Customer Value 2 & 2.67 & 1.788 & 0.994 & 0.867344 & 0.963 \\
\hline Customer Value 3 & 2.78 & 1.235 & 0.845 & 0.668386 & \\
\hline \multicolumn{6}{|l|}{ Customer Satisfaction } \\
\hline Customer Satisfaction1 & 2.89 & 0.878 & 0.910 & 0.889335 & 0.806 \\
\hline Customer Satisfaction2 & 2.32 & 0.714 & 0.778 & 0.578948 & \\
\hline
\end{tabular}

\section{Regression Results}

The following results were obtained after fitting the multiple linear regressions. The adjusted Rsquare in the table 4 shows that the dependent variable, (Value) is affected by $91.1 \%$ by independent variables (Product benefit, Image, Personnel, Service, Bonding, Emotions, Empathy, Reciprocity, Trust, commitment, communication, Conflict Handling, Monetary cost, Time cost, Energy cost and psychic cost). It shows that Product benefit, Image, Personnel, Service, Bonding, Emotions, Empathy, Reciprocity, Trust, commitment, communication, Conflict Handling, Monetary cost, Time cost, Energy cost and psychic cost are the factors responsible for satisfying customers. 


\begin{tabular}{|l|r|r|r|r|}
\hline \multicolumn{3}{|c|}{ Table 4 Model Summary } \\
\hline Model & $\mathrm{R}$ & R Square & $\begin{array}{c}\text { Adjusted R } \\
\text { Square }\end{array}$ & Std. Error of the Estimate \\
\hline 1 & $\begin{array}{r}967 \\
\mathrm{a}\end{array}$ & .935 & .921 & .23148 \\
\hline $\begin{array}{l}\text { a. Predictors: (Constant), Product benefit, Image, Personnel, Service, Bonding, } \\
\text { Emotions, Empathy, Reciprocity, Trust, commitment, communication, Conflict } \\
\text { Handling, Monetary cost, Time cost, Energy cost and psychic cost. }\end{array}$ \\
\hline
\end{tabular}

The overall model was also significant, tested with the help of ANOVA. The results are given in the following table.

Table V: ANOVA Results.

\begin{tabular}{|c|c|c|c|c|c|c|}
\hline \multicolumn{7}{|c|}{ Table 5 ANOVA } \\
\hline \multicolumn{2}{|c|}{ Model } & $\begin{array}{l}\text { Sum of } \\
\text { Squares }\end{array}$ & Df & $\begin{array}{l}\text { Mean } \\
\text { Square }\end{array}$ & $\mathrm{F}$ & Sig. \\
\hline \multirow{3}{*}{1} & Regression & 9.728 & 7 & 1.390 & 21.012 & $.000^{b}$ \\
\hline & Residual & 6.085 & 92 & .066 & & \\
\hline & Total & 15.813 & 99 & & & \\
\hline \multicolumn{7}{|c|}{ a. Dependent Variable: Value } \\
\hline \multicolumn{7}{|c|}{$\begin{array}{l}\text { b. Predictors: (Constant), Product benefit, Image, Personnel, Service, Bonding, } \\
\text { Emotions, Empathy, Reciprocity, Trust, commitment, communication, Conflict } \\
\text { Handling, Monetary cost, Time cost, Energy cost and psychic cost. }\end{array}$} \\
\hline
\end{tabular}

ANOVA table 5 is showing the level of significance. Through the table it is clear that all factors like Product benefit, Image, Personnel, Service, Bonding, Emotions, Empathy, Reciprocity, Trust, commitment, communication, Conflict Handling, Monetary cost, Time cost, Energy cost and psychic cost are related to satisfaction and that the relationship between them is significant as compared to alpha value $=0.05$. Table III shows the coefficients of all independent variables included in the model along with their respective P-values.

\section{Table VI: Regression Co-efficient}

The below table 6 shows that all of the factors are significant for insurance companies policy holders, i,e that all independent factors of the study has significant influence on the customer value. In the table, un-standardized coefficient shows that all-factors are positively affecting the value. 
International Journal of Managing Value and Supply Chains (IJMVSC) Vol. 4, No. 1, March 2013

\begin{tabular}{|c|c|c|c|c|c|c|}
\hline \multirow{2}{*}{\multicolumn{2}{|c|}{ Model }} & \multicolumn{2}{|c|}{ Unstandardized Coefficients } & \multirow{2}{*}{$\begin{array}{c}\begin{array}{c}\text { Standardized } \\
\text { Coefficients }\end{array} \\
\text { Beta }\end{array}$} & \multirow[t]{2}{*}{$\mathrm{T}$} & \multirow[t]{2}{*}{ Sig. } \\
\hline & & $\mathrm{B}$ & Std. Error & & & \\
\hline \multirow{17}{*}{1} & (Constant) & 1.138 & .252 & & 4.520 & .000 \\
\hline & Product Benefit & .119 & .009 & .393 & 12.683 & .000 \\
\hline & Image & .123 & .019 & .169 & 2.476 & .000 \\
\hline & Personnel & .149 & .011 & .132 & 1.624 & .000 \\
\hline & Services & .173 & .017 & .476 & 2.478 & .000 \\
\hline & Bonding A & .097 & .011 & .147 & 2.361 & .000 \\
\hline & Emotions B & .169 & .018 & .276 & 2.471 & .000 \\
\hline & Empathy C & .113 & .014 & .109 & 1.733 & .000 \\
\hline & Reciprocity D & .142 & .076 & .191 & 0.543 & .000 \\
\hline & Trust E & .025 & .010 & .164 & 2.491 & .000 \\
\hline & Commitment $\mathrm{F}$ & .197 & .071 & .144 & 1.549 & .000 \\
\hline & Communication $\mathrm{G}$ & .210 & .203 & .269 & 3.567 & .000 \\
\hline & $\begin{array}{c}\text { Conflict Handling } \\
\mathrm{H} \\
\end{array}$ & .136 & .024 & .316 & 1.789 & .000 \\
\hline & Monetary cost & .056 & .031 & .299 & 1.467 & .000 \\
\hline & Time Cost & .120 & .003 & .244 & 1.732 & .000 \\
\hline & Energy cost & .133 & .012 & .105 & 1.934 & .000 \\
\hline & Psychic cost & .110 & .134 & .142 & 1.564 & .000 \\
\hline
\end{tabular}

As it clear from the table, each and every factor is significantly related to 'Customer value'. Under the standardized coefficients it is evident that: 'value added Service has a significant relationship and positive contribution towards customer loyalty with standardize coefficient of 0.476 which mean that $47.6 \%$ of the respondents value generated because of value added services. Under the heading of services the antecedents of relation base marketing conflict handling is the first significant impact with standardize coefficient of 0.316 , communication with standardize coefficient of 0.269 , emotion with standardize coefficient of 0.276 . it means that among all factors value is prominently generated by value added services and within services conflict handling, communication and emotions are important factors.

While at cost side momentary cost or price of the product considered as a prominent factor standardize coefficient of 0.299 and time cost with standardize coefficient of 0.244 . Which means that $29.9 \%$ variation will come in customer value due the price or monetary cost of a product. While only $24.4 \%$ of the variation is shown in customer value due to time cost.

Table 6 shows that the overall model is highly significant $(\mathrm{P}=0.000)$. Which mean that there is a significant relationships exist between customer satisfaction and customer value (t-statistic $=$ 
29.433 and $\mathrm{P}$-value $=0.00$ ) which mean that customer value has a significant relationship with customer satisfaction.

\section{Relationship between Customer Satisfaction \& Customer Value}

Table 7 below shows that there is significant relationship between customer values and customer satisfaction. The model is significant with $\mathrm{p}$ value of 0.000 .

\begin{tabular}{|c|c|c|c|c|c|c|c|c|}
\hline \multicolumn{7}{|c|}{ Table 7 Regression Results } \\
\hline $\begin{array}{c}\text { S.N } \\
\text { o }\end{array}$ & $\begin{array}{c}\text { Dependent } \\
\text { Variables }\end{array}$ & $\begin{array}{c}\text { Independent } \\
\text { variable }\end{array}$ & $\begin{array}{c}\text { Adjusted R } \\
\text { square }\end{array}$ & F & B & $\begin{array}{c}\text { St. } \\
\text { Error }\end{array}$ & T & $\begin{array}{c}\text { P. } \\
\text { Value }\end{array}$ \\
\hline 1 & $\begin{array}{c}\text { Customer } \\
\text { satisfaction }\end{array}$ & Customer Value & 0.998 & 0.561 & 0.989 & 0.276 & 29.433 & 0.000 \\
\hline
\end{tabular}

Above table 7 represent that there is strong positive correlation between customer value and customer satisfaction. Results of the study shows that customer value explains $98.9 \%$ variation in customer satisfaction. In other words it is cleared that customer satisfaction is $98.9 \%$ dependent upon customer value.

\section{Findings and Conclusion of the Study}

Findings of the study shows that for customer satisfaction is dependent upon customer value. Study shows that customer value is strongly dependent upon four types of benefits and four types of cost. All the sub factors of cost and benefit has strongly influence on customer value. Greater the customer value greater the satisfaction. Research also concludes that product benefit and service benefit are important dimensions while creating customer value. Within the service value the antecedents of relation base marketing conflict handling with standardize coefficient of 0.316 , emotions with standardize coefficient of 0.276 , and communication with standardize coefficient of 0.69 play an important role and contribute more towards customer value. While in case of cost monetary cost with standardize coefficient of 0.299 and time cost with standardize coefficient of 0.244 . So firm must provide maximum value in shape of providing good product and service with communication, solving their conflict and holding emotions and reducing the customer monetary and time cost and will increase customer value which will lead greater customer satisfaction.

\section{References}

1. Chris, F. and Graham H. (2007), Relationship and Marketing Communication. Journal of relationship marketing, published by financial time's Prentice-Hall. Available on line: From Wikipedia, the free encyclopedia.

2. Gerpott,T. J., Rams,W., \& Schindler, A. (2001) Customer retention, loyalty, and satisfaction in the German mobile cellular telecommunications market Telecommunications Policy, 25, 249-269.

3. Hauser, J. R., Simester, D. I., \& Wernerfelt, B. (1994). Customer satisfaction incentives. Marketing Science, 13(4), 327-350.

4. Guo, L., Xiao, J. J., \& Tang, C. (2009). Understanding the psychological process underlying customer satisfaction and retention in a relational service. Journal of Business Research, 62, 1152.1159.

5. Lin, J. S. C., \& Wu, C. Y., (2011). The role of expected future use in relationship-based service retention. Managing Service Quality, 21(5), 535-551. 
International Journal of Managing Value and Supply Chains (IJMVSC) Vol. 4, No. 1, March 2013

6. Rust, R. T., \& Zahorik, A. J. (1993). Customer Satisfaction, Customer Retention and Market Share. Journal of retailing, 69 (2), 193-215.

7. Auh, S., \& Johnson, M. D. (2005). Compatibility effects in evaluations of satisfaction and loyalty. Journal of Economic psychology, 26, 35-57.

8. Bodet, G. (2008). Customer satisfaction and loyalty in service: two concepts, four construct several relationships. Journal of retailing and consumer services, 15, 156-162.

9. Shankar, Venkatesh, Amy K. Smith, and Arvind Rangaswamy (2003), "Customer satisfaction and loyalty in online and offline environments," International Journal of Research in Marketing, 20(2), 153-75.

10. Kim, K.J., jeong, I. J., Park, J. C., Park, Y. j., Kim, C. G., \& Kim, T. H. (2007). The impact of network performance on customer satisfaction and loyalty: High speed internet service case in Korea. Expert system with Applications, 32, 822-831.

11. Vesel, P., \& Zabkar, V. (2009). Managing customer loyalty through the mediating role of satisfaction in the DIY retail loyalty program. Journal of retailing and customer services, 16, 396406.

12. Shaker T. Ismail (2009) "The Effects of Relationship Marketing on Organizational Outcomes "An Applied Study in Jordanian Insurance Companies" European Journal of Social Sciences - Volume 12, Number 2 pp176-184

13. Kotler, P. and Keller, K.L. (2009) Marketing Management. Pearson International Edition. 13th Edition. Pearson Education Inc. Upper-saddle River.

14. Afshin Rahnama1, Abbas Alaei, Javad Shafaee and Ali Ariana (2012) "Evaluation of Relationship Marketing Dimension Effect on Degree of Customer's Loyalty of Insurance Industry in Iran" Journal of Basic and Applied Scientific Research 2(2)1842-1848

15. Shaker, T. Ismail and Basem, Y. Alsadi (2010) "Relationship Marketing and Organizational Performance Indicators" European Journal of Social Sciences - Volume 12, Number 4 pp545-557

16. Owais Mufti, Shahzad khan, Zafar Zaheer (2011) "Impact of Rational and Emotional Factors in Creating Consumer Motivation, a Study of Policy Holders of State Life Insurance Corporation in KPK, Pakistan" European journal of social sciences Volume 24, Number IV pp 546-552.

17. Chris, F. and Graham H. (2007), Relationship and Marketing Communication. Journal of relationship marketing, published by financial time's Prentice-Hall. Available on line: From Wikipedia, the free encyclopedia.

18. Wray B., Palmer A. and Bejou D (2007)."Using Neural Network Analysis to Evaluate BuyerSeller Relationships". European journal of Marketing, Vol.28 No10,pp.32-48.

19. Morgan, R. M and Hint, S.D. (1994). "The commitment- trust theory of relationship marketing" Journal of marketing, Volume 58, July, pp. 20-38.

20. Shahzad Khan (2012) "The Influence of Formal and Informal Sources on Consumer Buying Behavior" Global Journal of Management and Business Research Volume 12 Issue 12 pp1-5

21. Solomon, M., Bamossy, G., Askegaard, S. and Hogg, M. K (2006). Consumer Behavior, A European Perspective. 3rd edition. Pearson education limited Essex.

22. Skindaras, R. V. V. S. D. (2009). The Relationship between Price and Loyalty in Services Industry. ISSN 1392 - 2785 Inzinerine Ekonomika-Engineering Economics Commerce of engineering decisions, 3.

23. Bowen, J.T. and Chen. S.I. (2007)," The Relationship between Customer Loyalty and Customer Satisfaction", International Journal of Contemporary Hospitality Management, Vol.13 No.5, pp.213-217

24. Crosby, Lawrence A. \& Stephens, Nancy (2001),"Effects of Relationship Marketing on satisfaction, and prices in the life insurance industry", Journal of Marketing Research, Vol.XXIV.pp404.

25. Ndubisi, N.O. (2007)"Relationship Marketing and Customer Loyalty" Marketing intelligence \& Planning, vol.25No.1p98-106.

26. Shankar, V., Amy, K. Smith, A. K., \& Rangaswamy, A. (2003). Customer satisfaction and loyalty in online and offline environments. International journal of research in marketing, 20, 153-175. 
International Journal of Managing Value and Supply Chains (IJMVSC) Vol. 4, No. 1, March 2013

27. Wong, A. and shohal, A. (2002)"An examination of the relationship between trust, commitment and relationship quality", International Journal of retail \& Distribution Management, Vol.30, No.1,pp 34-50.

28. Zineldin, M. and Philipson S. (2007) "Kotler and Borden are not dead: myth of Relationship marketing and truth of 4ps", Journal of consumer Marketing, Vol. 24No. 4, pp, 229-241.

Author

Shahzad Khan is a Lecturer at City University of Science and information Technology Peshawar Pakistan. He Has done his MBA and MS from institute of Management Sciences Peshawar Pakistan and currently pursuing his PhD from international Islamic University Islamabad Pakistan. His Field of interest and specialization is Marketing and Business management. He Has more than 30 international publications.

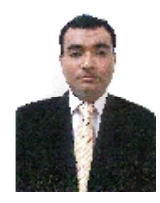

